\title{
Influence of maternal age on intracytoplasmic sperm injection outcome and global deoxyribonucleic acid methylation in women undergoing intracytoplasmic sperm injection cycle
}

\author{
Mohammed M. Laqqan ${ }^{1,2 *}$, Maged M. Yassin 3
}

\author{
${ }^{1}$ Department of Medical Laboratory Sciences, Islamic University, Gaza, Palestinian Territories \\ ${ }^{2}$ Department of Gynecology and Obstetrics, Saarland University "Graduate", Homburg, Germany \\ ${ }^{3}$ Department of Physiology, Al-Azhar University, Gaza, Palestinian Territories
}

Received: 21 April 2021

Accepted: 12 May 2021

\author{
*Correspondence: \\ Dr. Mohammed M. Laqqan, \\ E-mail: m.laqqan@gmail.com
}

Copyright: (C) the author(s), publisher and licensee Medip Academy. This is an open-access article distributed under the terms of the Creative Commons Attribution Non-Commercial License, which permits unrestricted non-commercial use, distribution, and reproduction in any medium, provided the original work is properly cited.

\begin{abstract}
Background: Intracytoplasmic sperm injection needs sufficient oocytes of high quality in order to increase the rate of fertilization and pregnancy. This study was designed to investigate the influence of maternal age on the ICSI outcomes in women undergoing to first ICSI cycle and to evaluate the influence of maternal age on global DNA methylation.

Methods: A total of 242 females were included in this study with a mean age of $30.5 \pm 7.3$ years. The participants were divided into three groups depending on women's age $\leq 25, \mathrm{~N}=70 ; 26-35, \mathrm{~N}=102$ and $>35, \mathrm{~N}=70$ ). The genomic DNA was isolated from the blood samples, then the global DNA methylation was evaluated using ELISA.

Results: A significant reduction has been found in the level of anti-Müllerian hormone (AMH), total number of the collected oocyte, mature oocytes, fertilized oocytes and number of embryos transferred in the older females compared to the younger group $(\mathrm{p}<0.001)$. While a significant increase has been found in global DNA methylation level in the older females compared to the younger group $(\mathrm{p}<0.001)$. A positive significant correlation has been found between global DNA methylation level and maternal age $(\mathrm{p}<0.001)$. In contrast, a negative significant correlation has been shown between AMH level, mature oocytes and maternal age $(\mathrm{p}<0.001)$.

Conclusions: Maternal age has a significant influence on the number of mature oocytes, number of embryos transferred and global DNA methylation. The pregnancy chance is more in the age group less than 35 years.
\end{abstract}

Keywords: Age, Female infertility, Global DNA methylation, ICSI outcomes

\section{INTRODUCTION}

Female infertility is defined as the inability to have a pregnancy after one year of unprotected intercourse if the female is under 35 years old. ${ }^{1}$ Approximately $10-15 \%$ of couples suffering from infertility and around $50 \%$ of cases are linked to male factor infertility. ${ }^{2}$ In general, female infertility is associated with ovulatory disorders, anatomical problems in the reproductive system, endometriosis, behavioral and environmental factors, genetic factors, and epigenetic regulation. ${ }^{1,3}$
Intracytoplasmic sperm injection (ICSI) is considered the best technique for the treatment of the following cases; infertility related to male factor, tubal factor infertility, unexplained infertility and females suffering from polycystic ovary syndrome (PCOS). ${ }^{4,5}$ Nevertheless, the success rate of human reproduction is dependent on the age at which females attempt to conceive6 where the female's fertility starts to decline after the age of 24 years and there is an acceleration of the decline after the age of 35 years until the menopause. ${ }^{7}$ Several previous studies showed a negative association between fecundity status, a success 
rate of the ICSI process and maternal age. ${ }^{8,9}$ The females advancing age is considered as one of the critical causes that leads to a reduction in ovarian reserve and ovarian response, a decrease in quantity and quality of oocyte, a reduction in the level of implantation hormones and in the fertilization rate. ${ }^{5}$ In contrast, other studies observed an increase in the maternal age ( $\geq 35$ years) does not influence the fertilization rate but has a high influence on the rate of aneuploidy in the blastocyst. ${ }^{3,10}$ The ICSI is still considered the safest assistance reproductive technique (ART), however, a previous study found a negative potential effect of ICSI on the epigenetic composition of the embryo and embryo development. ${ }^{11}$ The epigenetic includes histone modification, non-coding RNA action and DNA methylation and all of these processes are participate in the controlling of gene expression, chromatin structure and genome stability. ${ }^{12}$ DNA methylation is defined as the addition of a methyl group $\left(\mathrm{CH}_{3}\right)$ at position 5 of the cytosine ring, 13 and this process occurs on cytosine $(C)$ which following by guanine $(G)$ directly in the DNA sequence. ${ }^{14,15}$ DNA methylation process occurs by the DNA methyltransferases (DNMTs) enzyme which used to transfer a methyl group from the S-adenosylmethionine (SAM) to 5-cytosine of $\mathrm{CpG}$ dinucleotides to form 5-methylcytosine. ${ }^{16-18}$ A previous study found an association between the increase in DNA methylation level and advancing age. ${ }^{19}$ Due to the lack of available information and variances in the results of studies that evaluate the relationship between the global DNA methylation, ICSI outcomes and maternal age. This study was designed in order to investigate the influence of maternal age on the ICSI outcomes which included the number of collected oocytes, mature oocytes, fertilization rate, number of embryos transferred in women undergoing to first ICSI cycle, evaluate the impact of maternal age on the global DNA methylation and study the association between maternal age and other investigated clinical parameters.

\section{METHODS}

\section{Study population and sample criteria}

A total of two hundred and forty two women who underwent ICSI cycle in Al Basma fertility center were included in this study with an average age of $30.5 \pm 7.3$ years. The medical records were used by the researcher to gather the general and medical information which included females age, body mass index, menstrual history, hormones profile, number of collected oocytes, mature oocytes, immature oocytes, fertilized oocytes, number of embryos transferred and the pregnancy results. All of these parameters were retrospectively evaluated according to females age: age $\leq 25$ years $(\mathrm{N}=70)$, age $26-35$ years $(\mathrm{N}=$ $102)$ and age $>35$ years $(\mathrm{N}=70)$. The sample size calculations were based on the formula for cross-section studies. EPI-INFO statistical package version 3.5.1 was used with $95 \% \mathrm{CI}, 80 \%$ power and $50 \%$ proportion as conservative and $\mathrm{OR}>2$. The participants were selected according to the following inclusion criteria: women with normal body mass index (18.5-24.9), women exposed to the same ovarian stimulation protocol, women who have a regular menstrual cycle, couples suffering from infertility problem for at least five years, females suffering from infertility problem, no previous ICSI attempts and males partners age between 20-50 years and they have normal semen parameters. In contrast, the exclusion criteria were as follows: women age more than 50 years, alcohol intake, cigarette smokers, diabetes mellitus, women suffering from endometriosis, abnormal ovarian reserve parameters, and females suffering from endocrine disorders.

\section{Ovarian stimulation protocol}

All women included in this study have been undergoing ovarian stimulation by using GnRH antagonist protocols with a recombinant FSH. The ultrasonographic and the blood samples were collected from all women on the third day of the menstrual cycle. Briefly, the serum was separated by centrifugation at $3500 \mathrm{rpm}$ for 15 minutes and then all of the following hormones (basal level of E2, FSH, LH, PRL, TSH and AMH) were measured using the Tosoh instrument (AIA-360, Tokyo, Japan). The oocyte pickup was scheduled 33-36 hours after the administration of $5000 \mathrm{IU}$ to $10,000 \mathrm{IU}$ of hCG (pregnyl) depending upon the age of females and the degree of ovarian response. Embryo cleavage was evaluated after 16-18 hours from ICSI then the high-quality embryos (grade I) were transferred into the uterine cavity after 3 days from ICSI and that depending on the protocol used in the fertility center. All patients received luteal support with vaginal progesterone until a pregnancy test was performed after two weeks from embryo transferred. The cases were classified as pregnant women when the level of the $\beta$-hCG hormone arrived at more than $5 \mathrm{mIU} / \mathrm{ml}$. For this study, multiple pregnancies were regarded as one pregnancy.

\section{Nucleic acid isolation from blood samples}

The DNA was isolated from the female blood samples by using isolate II genomic DNA kit and all steps were performed according to the guidelines of the manufacturer company (Bioline, London, UK). The nanodrop spectrophotometer-2000 c (Thermo Scientific, USA) was used to evaluate the purity and the quantity of isolated DNA in order to ensure that the isolated DNA is sufficient and suitable for global sperm DNA methylation.

\section{Evaluation of global DNA methylation}

The MethylFlash ${ }^{\mathrm{TM}}$ methylated DNA quantification ELISA kit was used to evaluate the level of global DNA methylation (5-methylcytosine) in female blood samples, all the steps were performed according to the manufacturer's guidelines (Epigentek Group Inc, USA). Briefly, $100 \mathrm{ng}$ of extracted DNA was incubated with the 
DNA binding buffer solution at $37^{\circ} \mathrm{C}$ for $90 \mathrm{~min}$ (the blank, a positive and negative control have been used in triplicate during this assay). After washed the microwell three times, the methylated DNA capture solution was added to each well and incubated for one hour at room temperature. After that, the detection antibodies were added to each well and incubated at room temperature for $30 \mathrm{~min}$. After three-time washing, the developing solution was added to each well and incubated at room temperature in the dark place for 10 min, at the end of the 10 min the stop solution was added. The microplate ELISA reader was used to assess the absorbance at $450 \mathrm{~nm}$. The global DNA methylation status (ng) was calculated using the equation,

$5-\mathrm{mC}(\mathrm{ng})=\frac{(\text { sample } O D-\text { blank } O D)}{100}$.

\section{Statistics analysis}

The data of this study were analyzed using SPSS for windows software package version 24.0 (SPSS, Inc., Chicago, IL, USA). Data included in this study were nonnormally distributed (non-parametric) according to the value of the skewness test, kurtosis test, $\mathrm{Z}$ value and Shapiro test. The Kruskal-Wallis (H test) was applied to compare the means of quantitative variables among the study groups. The Spearman's rank test was used to evaluate the association between maternal age and the other investigated parameters. The results in the abovementioned procedures were accepted as statistically significant when $\mathrm{p}<0.05$.

\section{RESULTS}

Table 1 illustrates the general and clinical characteristics of the study population, where the mean age of females who participated in this study was $30.5 \pm 7.3$ years. As indicated in Table 2, a significant increase has been found in the level of follicle-stimulating hormone $(\mathrm{p}=0.008)$ and the female age $(p<0.001)$ among the different age groups. In contrast, a significant reduction has been found in the levels of luteinizing hormone, anti-Müllerian hormone and the estradiol hormone after stimulation $(\mathrm{p}=0.002, \mathrm{p}<0.001$, and $\mathrm{p}<0.001$, respectively) in the older females compared to the younger females group. No significant variation has been found among the females age groups in the Basal level of estradiol hormone $(\mathrm{p}=0.215)$, prolactin hormone level $(\mathrm{p}=0.881)$ and thyroid stimulating hormone level $(\mathrm{p}=0.060)$. As shown in Figure 1 , a significant elevation has been found in the global DNA methylation level in the older females compared to the younger females group $(\mathrm{p}<0.001)$. Regarding the ICSI parameters, the results showed a significant reduction in the total number of the collected oocyte, mature oocytes, fertilized oocytes, embryos transferred and the level of $B$-hCG hormone in older women compared to other women $(\mathrm{p}<0.001)$. Additionally, a significant variation has been found in the number of immature oocytes among the different age groups $(\mathrm{p}=0.009)$ (Table 3$)$.

Table 1: General and clinical characteristics of the study population ( $N=242)$.

\begin{tabular}{|c|c|c|c|c|}
\hline General and clinical characteristics & Mean & SD & Median & Range \\
\hline Females age (in years) & 30.52 & 7.27 & 29.00 & 30.00 \\
\hline Basal level of estradiol hormone (pg/ml) & 35.49 & 20.19 & 31.50 & 114.99 \\
\hline Follicle-stimulating hormone level (mIU/ml) & 7.66 & 2.95 & 7.10 & 23.41 \\
\hline Luteinizing hormone level (ng/ml) & 5.68 & 3.68 & 4.80 & 30.90 \\
\hline Prolactin hormone level (ng/ml) & 16.76 & 19.04 & 14.10 & 199.30 \\
\hline Thyroid stimulating hormone level (uIU/ml) & 2.00 & 1.25 & 1.70 & 9.28 \\
\hline Anti-Müllerian hormone level (ng/ml) & 2.75 & 2.79 & 1.80 & 16.99 \\
\hline Estradiol hormone level after stimulation (pg/ml) & $1,796.08$ & 887.47 & $1,690.50$ & $6,622.00$ \\
\hline Global DNA methylation level (ng/ $\mu \mathrm{l})$ & 5.26 & 1.93 & 5.45 & 6.70 \\
\hline Total number of collected oocyte & 7.57 & 3.41 & 8.00 & 16.00 \\
\hline Number of mature oocytes & 6.00 & 2.81 & 6.00 & 15.00 \\
\hline Number of immature oocytes & 1.58 & 1.82 & 1.00 & 12.00 \\
\hline Number of fertilized oocytes & 4.69 & 1.95 & 5.00 & 10.00 \\
\hline Oocytes fertilization rate & 66.40 & 21.08 & 66.67 & 100.00 \\
\hline Number of embryos transferred & 3.37 & 1.59 & 4.00 & 8.00 \\
\hline B-hCG hormone level (mIU/ml) & 5.09 & 3.40 & 3.56 & 12.49 \\
\hline
\end{tabular}

$\mathrm{SD}=$ standard deviation; $\beta-\mathrm{hCG}=$ beta human chorionic gonadotropin hormone. 
Table 2: Comparison of clinical parameters among the different age groups $(\mathrm{N}=\mathbf{2 4 2})$.

\begin{tabular}{|c|c|c|c|c|c|c|c|c|c|c|}
\hline \multirow{2}{*}{$\begin{array}{l}\text { General and clinical } \\
\text { parameters }\end{array}$} & \multicolumn{3}{|c|}{ Age $\leq \mathbf{2 5}$ years $(\mathbf{N}=\mathbf{7 0})$} & \multicolumn{3}{|c|}{ Age $26-35$ years $(\mathrm{N}=102)$} & \multicolumn{3}{|c|}{ Age $>35$ years $(N=70)$} & \multirow{2}{*}{$P$ value } \\
\hline & Mean & $\mathrm{SD}$ & Median & Mean & SD & Median & Mean & SD & Median & \\
\hline $\begin{array}{l}\text { Females age (in } \\
\text { years) }\end{array}$ & 22.46 & 2.08 & 23.00 & 29.53 & 2.68 & 29.00 & 40.04 & 3.22 & 39.00 & $<0.001$ \\
\hline $\begin{array}{l}\text { Basal level of } \\
\text { estradiol hormone } \\
\text { (pg/ml) }\end{array}$ & 31.91 & 18.49 & 29.00 & 38.40 & 22.36 & 35.50 & 34.81 & 18.00 & 32.50 & 0.215 \\
\hline $\begin{array}{l}\text { Follicle-stimulating } \\
\text { hormone level } \\
(\mathrm{mIU} / \mathrm{ml})\end{array}$ & 7.04 & 3.27 & 6.65 & 7.62 & 2.46 & 7.00 & 8.33 & 3.15 & 7.80 & 0.008 \\
\hline $\begin{array}{l}\text { Luteinizing hormone } \\
\text { level (ng/ml) }\end{array}$ & 6.11 & 4.37 & 5.25 & 6.06 & 3.62 & 5.15 & 4.69 & 2.75 & 3.80 & 0.002 \\
\hline $\begin{array}{l}\text { Prolactin hormone } \\
\text { level }(\mathrm{ng} / \mathrm{ml})\end{array}$ & 15.60 & 8.34 & 14.30 & 15.51 & 10.26 & 13.50 & 19.75 & 32.09 & 15.70 & 0.881 \\
\hline $\begin{array}{l}\text { Thyroid stimulating } \\
\text { hormone level } \\
\text { (uIU/ml) }\end{array}$ & 1.71 & 0.92 & 1.60 & 2.20 & 1.59 & 1.70 & 2.00 & 0.89 & 1.90 & 0.060 \\
\hline $\begin{array}{l}\text { Anti-Müllerian } \\
\text { hormone level } \\
(\mathbf{n g} / \mathbf{m l})\end{array}$ & 3.81 & 2.93 & 3.00 & 2.94 & 3.15 & 1.80 & 1.41 & 1.01 & 1.20 & $<0.001$ \\
\hline $\begin{array}{l}\text { Estradiol hormone } \\
\text { level after } \\
\text { stimulation (pg/ml) }\end{array}$ & $2,022.50$ & 858.32 & $2,046.50$ & $1,913.72$ & 948.13 & $1,787.00$ & $1,398.24$ & 682.14 & $1,457.50$ & $<0.001$ \\
\hline
\end{tabular}

All values are expressed as mean $\pm \mathrm{SD} ; \mathrm{SD}=$ standard deviation; $\mathrm{p}<0.05=$ significant; $\mathrm{p} \geq 0.05=$ not significant.

Table 3: Comparison of ICSI outcome among the different age groups $(\mathrm{N}=242)$.

\begin{tabular}{|c|c|c|c|c|c|c|c|c|c|c|}
\hline \multirow{2}{*}{ ICSI outcome } & \multicolumn{3}{|c|}{$\begin{array}{l}\text { Age } \leq 25 \text { years } \\
(\mathrm{N}=70)\end{array}$} & \multicolumn{3}{|c|}{$\begin{array}{l}\text { Age 26-35 years } \\
(\mathrm{N}=102)\end{array}$} & \multicolumn{3}{|c|}{$\begin{array}{l}\text { Age }>35 \\
(\mathrm{~N}=70)\end{array}$} & \multirow{2}{*}{ P value } \\
\hline & Mean & SD & Median & Mean & $\mathrm{SD}$ & Median & Mean & SD & Median & \\
\hline $\begin{array}{l}\text { Total number of } \\
\text { collected oocyte }\end{array}$ & 8.60 & 3.23 & 9.00 & 8.10 & 3.41 & 8.00 & 5.79 & 2.89 & 6.00 & $<0.001$ \\
\hline $\begin{array}{l}\text { Number of mature } \\
\text { oocytes }\end{array}$ & 7.09 & 2.80 & 7.00 & 6.19 & 2.69 & 6.00 & 4.63 & 2.46 & 5.00 & $<0.001$ \\
\hline $\begin{array}{l}\text { Number of } \\
\text { immature oocytes }\end{array}$ & 1.51 & 1.44 & 1.00 & 1.91 & 2.13 & 1.00 & 1.16 & 1.58 & 1.00 & 0.009 \\
\hline $\begin{array}{l}\text { Number of fertilized } \\
\text { oocytes }\end{array}$ & 5.30 & 1.77 & 5.00 & 4.89 & 1.92 & 5.00 & 3.80 & 1.88 & 4.00 & $<0.001$ \\
\hline $\begin{array}{l}\text { Oocytes fertilization } \\
\text { rate }\end{array}$ & 64.60 & 16.78 & 62.50 & 64.82 & 19.89 & 66.67 & 70.49 & 25.83 & 70.00 & 0.110 \\
\hline $\begin{array}{l}\text { Number of embryos } \\
\text { transferred }\end{array}$ & 3.77 & 1.51 & 4.00 & 3.51 & 1.63 & 4.00 & 2.76 & 1.43 & 3.00 & $<0.001$ \\
\hline $\begin{array}{l}\text { B-hCG hormone } \\
\text { level }(\mathrm{mIU} / \mathrm{ml})\end{array}$ & 6.01 & 3.45 & 6.45 & 5.50 & 3.38 & 4.20 & 3.57 & 2.88 & 2.51 & $<0.001$ \\
\hline
\end{tabular}

All values are expressed as mean $\pm \mathrm{SD}, \mathrm{SD}=$ standard deviation; $\beta$-hCG=beta human chorionic gonadotropin hormone,

$\mathrm{p}<0.05=$ significant, $\mathrm{p} \geq 0.05=$ not significant.

Table 4: Relationship between the maternal age and other clinical parameters $(\mathrm{N}=242)$.

\begin{tabular}{|lllllll|}
\hline Clinical parameters & $\mathbf{r}$ & P value & Clinical parameters & r & P value \\
\hline $\begin{array}{l}\text { Basal level of estradiol hormone } \\
\text { (pg/ml) }\end{array}$ & 0.060 & 0.332 & Total number of collected oocyte & -0.323 & $<0.001$ \\
\hline $\begin{array}{l}\text { Follicle-stimulating hormone level } \\
\text { (mIU/ml) }\end{array}$ & 0.206 & $<0.001$ & Number of mature oocytes & -0.321 & $<0.001$ \\
\hline Luteinizing hormone level $(\mathbf{n g} / \mathbf{m l})$ & -0.173 & 0.007 & Number of immature oocytes & -0.137 & 0.033 \\
\hline Prolactin hormone level $(\mathbf{n g} / \mathbf{m l})$ & -0.020 & 0.808 & Number of fertilized oocytes & -0.296 & $<0.001$ \\
\hline $\begin{array}{l}\text { Thyroid stimulating hormone level } \\
\text { (uIU/ml) }\end{array}$ & 0.151 & 0.019 & Oocytes fertilization rate & 0.145 & 0.024 \\
\hline
\end{tabular}




\begin{tabular}{|llllll|}
\hline Clinical parameters & $\mathbf{r}$ & $\mathbf{P}$ value & Clinical parameters & $\mathbf{r}$ & P value \\
\hline $\begin{array}{l}\text { Anti-Müllerian hormone level } \\
\text { (ng/ml) }\end{array}$ & -0.411 & $<0.001$ & Number of embryos transferred & -0.255 & $<0.001$ \\
\hline Global DNA methylation $(\mathbf{n g} / \mathbf{\mu l})$ & 0.883 & $<0.001$ & B-hCG hormone level $(\mathrm{mIU} / \mathrm{ml})$ & -0.261 & $<0.001$ \\
\hline $\begin{array}{l}\text { Estradiol hormone level after } \\
\text { stimulation }(\mathbf{p g} / \mathbf{m l})\end{array}$ & -0.273 & $<0.001$ & & & \\
\hline
\end{tabular}

Spearman's rank test, $r$, correlation coefficient, $\beta$-hCG=beta human chorionic gonadotropin hormone; $p<0.05=$ significant, $p \geq 0.05=$ not significant.

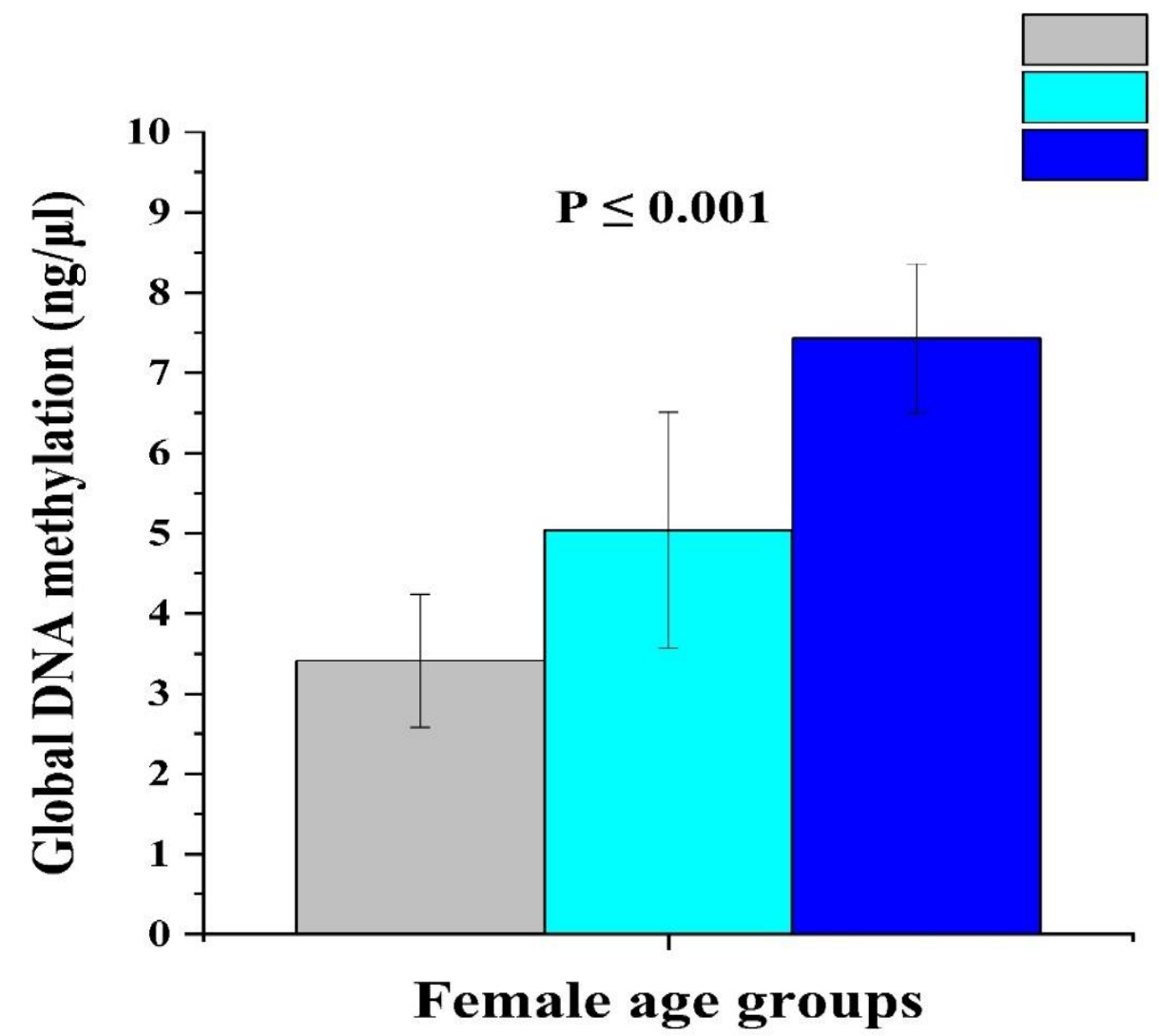

$\mathrm{P}<0.05=$ significant; $\mathrm{p} \geq 0.05=$ not significant.

Figure 1: Global DNA methylation status among the different age groups.

\section{Correlation between the maternal age and other clinical parameters}

A positive significant correlation has been found between the status of global DNA methylation, the oocyte fertilization rate and the maternal age $(\mathrm{p}<0.001$ and $\mathrm{p}=0.024$, respectively). In addition, a positive significant association has been observed between the levels of follicle-stimulating hormone, the thyroid-stimulating hormone and the maternal age $(\mathrm{p}<0.001, \mathrm{p}=0.019$, respectively). In contrast, a negative significant association has been found between the levels of antiMüllerian hormone, luteinizing hormone, the number of immature oocytes and the maternal age $(p<0.001, p=0.007$, and $\mathrm{p}=0.033$, respectively). These results have shown a negative significant association between the level of estradiol hormone after stimulation, the total number of the collected oocyte, the mature oocytes, the fertilized oocytes, the transferred embryos, the level of $B-h C G$ and the maternal age $(\mathrm{p}<0.001)$ (Table 4$)$.

\section{DISCUSSION}

Women's fertility starts to decline many years before arriving at the beginning of menopause. ${ }^{20} \mathrm{~A}$ previous study found a negative association between the ovarian reserve, ovarian response to stimulation and maternal age. ${ }^{21} \mathrm{~A}$ previous study has been shown a rapid reduction in the fecundity of females after the age of 35 years, where the advancing female's age influence negatively on the ovarian reserve, the number, the fertilization rate, the quality of oocyte and success after ICSI. ${ }^{22,23}$ Several couples believe that ICSI techniques are not influenced by the age of females. ${ }^{24}$ Whereas, the data of fertility centers in the U.S. showed that a decline in the rates of live birth per cycle of ICSI as $33.1 \%, 8.3 \%, 3.2 \%$ and $0.8 \%$ at the following ages 35 years, 41-42 years, 43-44 years and >44 years, 
respectively. ${ }^{25}$ The results of this study showed a significant reduction in the level of estradiol hormone after stimulation, the total number of the collected oocyte, mature oocytes, fertilized oocytes. In contrast, a significant variation has been found in the number of immature oocytes among the different age groups. These findings agree with the results of a previous study that showed that women age up to 25 years had a higher number of collected oocytes compared to other age groups. ${ }^{5}$ Furthermore, these findings are consistent with a previous study that showed that the highest number of collected oocytes was found in females aged less than 30 years. ${ }^{26}$ Another study showed that the chance of pregnancy affected by the female's age 27 where the highest number of pregnancies have been found in women age between 19 years to 26 years compared to women located in the age group 27-29 years. ${ }^{28}$ Nevertheless, these findings not in line with a study prepared by Silber and his colleagues who showed that the female age had no significant influence on the number of successful pregnancies. ${ }^{29}$ The present results found a significant variation in the number of embryos transferred among the different age groups where the lowest number of embryos transferred was found in the age group $>35$ and this result is consistent with a previous study. ${ }^{30}$

The present results showed a significant reduction in the level of $\beta$-hCG hormone among the different age groups, where the lowest level of $\beta$-hCG hormone was found in the age group $>35(3.57 \mathrm{mIU} / \mathrm{ml})$. All of these results are in line with a study that found that the success rate of ICSI significantly declines in women with an age of 40 years. ${ }^{31}$ Consequently, the chance of getting a positive pregnancy will be reduced in females aged more than 40 years. ${ }^{32}$ No significant variation in the fertilization rate of oocytes among the different age groups and this finding agrees with a previous study. ${ }^{33} \mathrm{~A}$ negative correlation has been observed between the levels of anti-Müllerian hormone, the luteinizing hormone, the estradiol after stimulation, the level of $\beta-h C G$, the total number of the collected oocyte, the mature oocytes, the fertilized oocytes, the immature oocytes and the transferred embryo and the maternal age. All of these findings are in agreement with previous studies that reported that the increase in female age plays a critical role in the reduction of ovarian response degree, consequently, a decrease in the number of the collected oocyte and an increase in the rate of ICSI failure. ${ }^{29,33}$ Also, these findings are matching with a previous study that showed that older women have a high chance of ICSI outcomes failure compared to younger women. ${ }^{34}$ The maternal age is associated negatively with the ICSI outcomes and these results are matching with another study. ${ }^{35}$ In contrast, a positive correlation has been found between the fertilization rate, follicle-stimulating hormone level, the thyroid-stimulating hormone level and the maternal age. However, these findings did not match with previous studies that did not found a significant association between maternal age and the oocyte fertilization rate. ${ }^{36}$ On the other hand, the present study observed a significant increase in the status of global DNA methylation among the different age groups where the highest level of global DNA methylation $(7.43 \mathrm{ng} / \mu \mathrm{l})$ has been found in the age group $>35$ years. A positive association has been found between the status of global DNA methylation and maternal age. These findings are matching with the study designed by Marshall and his colleagues where they found an increase in the level of global DNA methylation in aged women compared to young women. ${ }^{19}$ It is worth mentioning that DNA methylation plays a critical role in transcriptional suppression and chromatin compaction. Therefore, the increase in the level of global DNA methylation with increased female age is a contributor to the alteration of oocyte transcription which influences the development of the embryo. ${ }^{18}$

\section{CONCLUSION}

Maternal age has a significant influence on the number of mature oocytes, fertilized oocytes, number of embryos transferred, the success of the ICSI, and global DNA methylation. The pregnancy chance is more in the age group less than 35 years.

\section{Funding: No funding sources Conflict of interest: None declared \\ Ethical approval: The study was approved by the Institutional Ethics Committee}

\section{REFERENCES}

1. Hakimi O, Cameron LC. Effect of exercise on ovulation: a systematic review. Sports Med. 2017;47(8):1555-67.

2. Kumar N, Singh AK. Trends of male factor infertility, an important cause of infertility: a review of literature. $\mathrm{J}$ Hum Reprod Sci. 2015;8(4):191-6.

3. Capalbo A, Hoffmann ER, Cimadomo D, Maria Ubaldi F, Rienzi L. Human female meiosis revised: new insights into the mechanisms of chromosome segregation and aneuploidies from advanced genomics and time-lapse imaging. Hum Reprod Update. 2017;23(6):706-22.

4. Khalaf Y, El-Toukhy T, Coomarasamy A, Kamal A, Bolton V, Braude P. Selective single blastocyst transfer reduces the multiple pregnancy rate and increases pregnancy rates: a pre-and postintervention study. BJOG Int J Obstet Gynaecol. 2008;115:385-90.

5. Rehman R, Mahmood H, Syed F, Syed H, Gul H. Intracytoplasmic sperm injection and advanced maternal age: Success or treatment failure. Pakistan J Pharmaceut Sci. 2019;32(4):1495.

6. Mills M, Rindfuss RR, McDonald P, TeVelde E, ESHRE Reproduction and Society Task Force. Why do people postpone parenthood? Reasons and social policy incentives. Hum Reprod Update. 2011;17(6):848-60.

7. Karim SH. The effect of maternal age on the outcomes of in vitro fertilization Sulaimani region. Mustansiriya Med J. 2016;15(1):70-4.

8. Nelson SM, Lawlor DA. Predicting live birth, preterm delivery, and low birth weight in infants born from in vitro fertilisation: a prospective study of 144,018 treatment cycles PLoS Med. 2011;8:1000386.

9. Schmidt L, Sobotka T, Bentzen JG, Nyboe Andersen A, ESHRE Reproduction and Society Task Force. 
Demographic and medical consequences of the postponement of parenthood. Hum Reprod Update. 2012;18(1):29-43.

10. Grøndahl ML, Christiansen SL, Kesmodel US, Agerholm IE, Lemmen JG, Lundstrøm P, et al. Effect of women's age on embryo morphology, cleavage rate and competence-a multicenter cohort study PLoS One. 2017;12(4):0172456.

11. Kohda T, Ishino F. Embryo manipulation via assisted reproductive technology and epigenetic asymmetry in mammalian early development. Biolog Sci. 2013;368(1609):20120353.

12. Brenet F, Moh M, Funk P, Feierstein E, Viale AJ, Socci ND, Scandura JM. DNA methylation of the first exon is tightly linked to transcriptional silencing. PloS One. 2011;6:14524.

13. Schübeler D. Function and information content of DNA methylation. Nature. 2015;517:321-6.

14. Zaghlool SB, Al-Shafai M, Al Muftah WA, Kumar P, Falchi M, Suhre K. Association of DNA methylation with age, gender, and smoking in an Arab population. Clinical Epigenet. 2015;7(6):1-2.

15. Celik H, Kramer A, Challen GA. DNA methylation in normal and malignant hematopoiesis. Int J Hematol. 2016;103:617-26.

16. Hirasawa R, Chiba H, Kaneda M, Tajima S, Li E, Jaenisch R, Sasaki H. Maternal and zygotic Dnmt1 are necessary and sufficient for the maintenance of DNA methylation imprints during preimplantation development. Genes Dev. 2008;22(12):1607-16.

17. Li E, Zhang Y. DNA methylation in mammals. Cold Spring Harbor Perspect Biol. 2014;6:019133.

18. Heyn H, Vidal E, Ferreira HJ, Vizoso M, Sayols S, Gomez A, et al. Epigenomic analysis detects aberrant super-enhancer DNA methylation in human cancer. Genome Biol. 2016;17:1-6.

19. Marshall KL, Wang J, Ji T, Rivera RM. The effects of biological aging on global DNA methylation, histone modification, and epigenetic modifiers in the mouse germinal vesicle stage oocyte. Animal Reproduct. 2018;15(4):1253-67.

20. Menken J, Trussell J, Larsen U. Age and infertility. Science. 1986;233(3):1389-94.

21. LaMarca A, Spada E, Sighinolfi G, Argento C, Tirelli A, Giulini S, et al. Age-specific nomogram for the decline in antral follicle count throughout the reproductive period. Fertil Steril. 2011;95(2):684-8.

22. Balasch J. Ageing and infertility: an overview. Gynecol Endocrinol. 2010;26(12):855-60.

23. Wyndham N, Figueira PG, Patrizio P. A persistent misperception: assisted reproductive technology can reverse the "aged biological clock". Fertil Steril. 2012;97(5):1044-7.

24. Hornstein MD. State of the ART: assisted reproductive technologies in the United States. Reproduct Sci. 2016;23:1630-3.
25. Tan TY, Lau MS, Loh SF, Tan HH. Female ageing and reproductive outcome in assisted reproduction cycles. Singapore Med J. 2014;55(6):305-9.

26. Chan CH, Chan TH, Peterson BD, Lampic C, Tam MY. Intentions and attitudes towards parenthood and fertility awareness among Chinese university students in Hong Kong: a comparison with Western samples. Human Reproduct. 2015;30(2):364-72.

27. Dunson DB, Baird DD, Colombo B. Increased infertility with age in men and women. Obstet Gynecol. 2004;103(1):51-6.

28. Silber SJ, Nagy Z, Devroey P, Camus M, VanSteirteghem AC. The effect of female age and ovarian reserve on pregnancy rate in male infertility: treatment of azoospermia with sperm retrieval and intracytoplasmic sperm injection. Human Reproduct. 1997;12(12):2693-700.

29. Çiray HN, Ulug U, Tosun S, Erden HF, Bahceci M. Outcome of 1114 ICSI and embryo transfer cycles of women 40 years of age and over. Reproduct Biomed Online. 2006;13(4):516-22.

30. Dew JE, Don RA, Hughes GJ, Johnson TC, Steigrad SJ. The influence of advanced age on the outcome of assisted reproduction. J Assist Reproduct Genet. 1998;15(4):2104.

31. Ron-El R, Raziel A, Strassburger D, Schachter M, Kasterstein E, Friedler S. Outcome of assisted reproductive technology in women over the age of 41 . Fertil Steril. 2000;74:471-5.

32. Moon SY, Kim SH, Jung BJ, Jee BC, Suh CS, Lee JY. Influence of female age on pregnancy outcome in in vitro fertilization and embryo transfer patients undergoing intracytoplasmic sperm injection. J Obstet Gynaecol Res. 2000;26(1):49-54.

33. Kenny LC, Lavender T, McNamee R, O’Neill SM, Mills $\mathrm{T}$, Khashan AS. Advanced maternal age and adverse pregnancy outcome: evidence from a large contemporary cohort. PloS One. 2013;8(2):56583.

34. Bellver J, Ayllón Y, Ferrando M, Melo M, Goyri E, Pellicer A, et al. Female obesity impairs in vitro fertilization outcome without affecting embryo quality. Fertil Steril. 2010;93(2):447-54.

35. Choi HW, Park YS, Lee SH, Lim CK, Seo JT, Yang KM. Effects of maternal age on embryo quality and pregnancy outcomes using testicular sperm with intracytoplasmic sperm injection. Clinic Experiment Reproduct Med. 2016;43(4):221.

36. Ahmed M, Shareef O, Adam I, Rayis D. Maternal age and intracytoplasmic sperm injection outcome in infertile couples at Khartoum, Sudan. F1000Res. 2015;4:1339.

Cite this article as: Laqqan MM, Yassin MM. Influence of maternal age on intracytoplasmic sperm injection outcome and global DNA methylation in women undergoing intracytoplasmic sperm injection cycle. Int J Reprod Contracept Obstet Gynecol 2021;10:2185-91. 